\title{
Broca aphasia
}

\author{
Takashi Watari, ${ }^{1}$ Taro Shimizu, ${ }^{1}$ Yasuharu Tokuda ${ }^{2}$
}

${ }^{1}$ Department of Internal Medicine, Tokyo Joto Hospital, Tokyo, Japan

${ }^{2}$ Japan Community Healthcare Organization, Tokyo, Japan

\section{Correspondence to} Dr Taro Shimizu, shimizutaro7@gmail.com

Accepted 6 December 2014

\section{DESCRIPTION}

An 80-year-old Japanese woman presented with sudden onset of speech disturbance and confusion. She was riding a bicycle when she suddenly felt unwell and subsequently noticed she could not find words to express her thoughts. A pedestrian found her sitting on the ground, at a loss for words and looking confused. She was brought to the emergency department for evaluation. On examination, she was alert, but looked very anxious, frustrated and confused. She was not oriented to time, place and person. She spoke hesitantly and non-fluently, she seemed not to be able to find words to respond (speaking and writing) to the physician's questions. She also showed impairment in repetition and comprehension to questions with complex syntax. The rest of the neurological examination was normal. Laboratory studies showed high cholesterol and elevated glycated haemoglobin of 8.2.

Diffusion-weighted MRI revealed acute infarction involving the Broca area (figure 1). MR angiography showed severe stenosis of the distal left middle cerebral artery (figure 2). The patient was diagnosed as pure motor aphasia (Broca aphasia). After conservative treatment with a speech therapist, she made an uneventful recovery.

Broca aphasia is characterised by severe impairment in expressing speech and writing. ${ }^{1}$ Comprehension is sometimes affected. Broca aphasia stems from neurological damage to the Broca area. The differential diagnosis is broad, encompassing vascular, infectious, inflammatory or degenerative conditions (box 1). Also, some cases with limited symptoms, as seen in this case, can

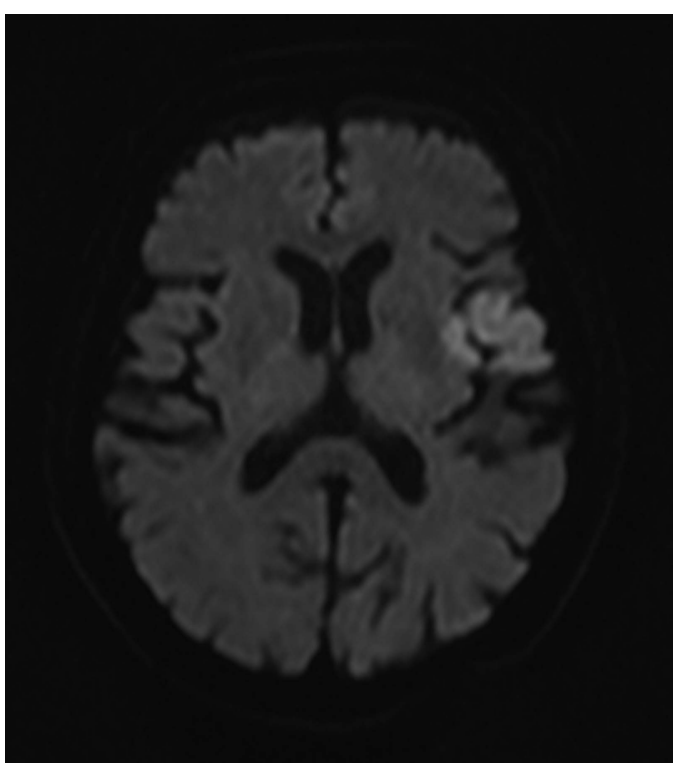

Figure 1 Diffusion-weighted MRI showing ischaemic findings involving the Broca area.

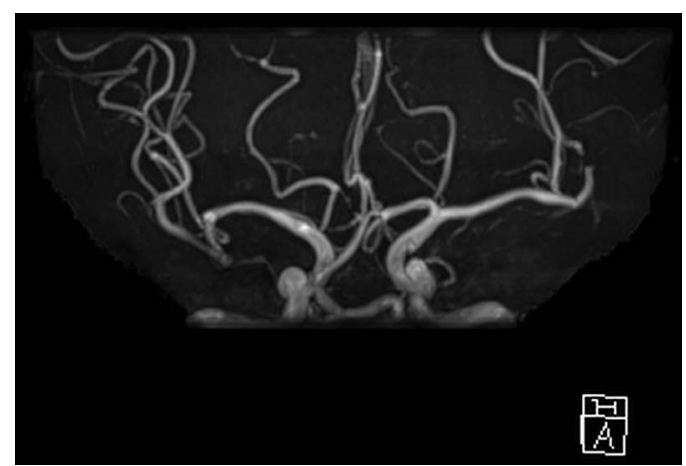

Figure 2 Three-dimensional MR angiography showing a signal loss (arrows) at the distal point of the left middle cerebral artery.

mislead clinicians to other diagnoses such as herpes encephalitis, Alzheimer's disease and conversion disorder. ${ }^{2}$

\section{Box 1 Differential diagnosis of Broca} aphasia

\section{Ischaemic disease}

Cerebral infarction

Transient ischaemic attack

\section{Haemorrhage}

Intracerebral haemorrhage

Traumatic injury

Subdural haematoma

Subarachnoid haemorrhage

\section{Infection}

Herpes encephalitis

West Nile encephalitis

Bacterial infection/abscess

Fungal abscess

Prion disease

Toxoplasmosis

Lyme disease

Degeneration

Alzheimer's disease

Primary progressive aphasia

Amyotrophic lateral sclerosis

Demyelination

Multiple sclerosis

Acute disseminated encephalomyelitis

Tumour

Primary brain tumour

Brain metastases

Others

Sarcoidosis

Migraine

Seizure

Conversion disorder

Wernicke's encephalopathy 


\section{Learning points}

- Broca aphasia should be suspected when a patient has difficulty in repetition and naming, and if dysfluency or inaccuracy of expression of speech and writing are detected.

- The diagnosis is sometimes difficult because of the limited manifestation of symptoms.
Contributors TW wrote the manuscript. TS and YT revised the manuscript.

Competing interests None.

Patient consent Obtained.

Provenance and peer review Not commissioned; externally peer reviewed.

\section{REFERENCES}

1 Daroff RB, et al. Bradley's Neurology in Clinical Practice. 2012:134-5.

2 Ochfeld E, Newhart M, Molitoris J, et al. Ischemia in Broca area is associated with Broca aphasia more reliably in acute than in chronic stroke. Stroke 2010;41:325-30.

Copyright 2014 BMJ Publishing Group. All rights reserved. For permission to reuse any of this content visit http://group.bmj.com/group/rights-licensing/permissions.

BMJ Case Report Fellows may re-use this article for personal use and teaching without any further permission.

Become a Fellow of BMJ Case Reports today and you can:

- Submit as many cases as you like

- Enjoy fast sympathetic peer review and rapid publication of accepted articles

- Access all the published articles

- Re-use any of the published material for personal use and teaching without further permission

For information on Institutional Fellowships contact consortiasales@bmjgroup.com

Visit casereports.bmj.com for more articles like this and to become a Fellow 